\title{
Quality of Family Education and Its Effect on Fulfilling Child Care Rights: A National Survey
}

\author{
Budiharjo \\ Universitas Prof. Dr. Moestopo (Beragama), Indonesia \\ Received June 26, 2019; Revised July 31, 2019; Accepted September 3, 2019
}

Copyright $\bigcirc 2019$ by authors, all rights reserved. Authors agree that this article remains permanently open access under the terms of the Creative Commons Attribution License 4.0 International License

\begin{abstract}
This study elaborates on the quality of family education in fulfilling childcare rights. The results of the study found that family resilience is a factor that influences the quality of childcare. The resilience of the family in this study was measured by three indicators, namely education and parental knowledge regarding care, parental involvement in child care, availability and adequacy of time to communicate with children. This study found that the quality of education and knowledge of parents related to childcare is still weak, with only $27.9 \%$ of fathers and $36.9 \%$ of mothers seeking information on caring for children before marriage and only $38.9 \%$ of fathers and $56.2 \%$ of mothers seek information on caring for children after marriage. Parental involvement directly in the process of parenting is also still low, only $26.2 \%$ of Fathers and $25.8 \%$ of Mothers stated that the process of parenting was not helped and was not transferred to others. The quantity and quality of communication time of parents with children is also still very minimal, in quantity the average time to communicate with children is only 1 hour per day which is $47.1 \%$ for Father and $40.6 \%$ for mother. The weak education of parents in the process of fulfilling child care rights has the potential to lead to not maximally developing children in the family.
\end{abstract}

Keywords Family Education, Parents' Knowledge, Parental Involvement, Child Care Rights, Child Education

\section{Introduction}

The family is currently a miniature child in the future, in the family of children grows, develops and learns the values of life. Family quality determines the quality of children in the future. One of the qualities of the family is determined by the quality of education, in the aspect of fulfilling child care rights, parental education has a very significant role in the process of child development
(Epstein et al., 2018; Coleman, 2018; Halmatov, 2018). Because one of the rights of the child is directly taken care of by his or her parents, child care is an effort to fulfill the needs for affection, attachment, safety, and well-being that are permanent and sustainable in the best interests of the child (Crittenden, 2013; Kagan, 2014). Indonesia's social ministry (2013) in ministerial regulation No. 21 of 2013 stated that child care was carried out either by parents or family to the third degree or foster parents, foster parents, guardians, and caregivers residential based as a last alternative.

Parents, fathers and mothers are certainly obliged to provide the best and quality care for their children. Quality care is characterized by the fulfillment of the right of child growth and development properly in parenting parents (Handayani \& Munawar, 2015). The quality of parenting by parents is reflected in the attitudes, ways, actions and skills of parents in caring for children, direct involvement of parents in the care process, quantity and quality when parents communicate with children (Güder \& Ata, 2018). However, nowadays most parents become fathers and mothers without careful preparation. Being a parent and caring for children takes place naturally. Some others imitate the way their parents care. Even in the child care process, some parents are not directly involved, but child care is replaced by the substitute family (Smith \& Hancock, 2010; see also. Firat, 2018). In terms of parenting, it requires skills and knowledge.

According to Mubarok (2016), the skills in parenting consist of parents' ability to listen, emotional awareness, self-regulation in parenting relationships and affection for children. Direct involvement of parents in the process of caring for and caring for children is important to do, which is a medium to build attachment to children with parents. Through the activity of hugging, holding, bathing, kissing and other joint activities, the stimulation will build strong relationships between children and parents. Parental stimulation of children has an effect on increasing child development, where parents who more 
often provide stimulation lead to better child development (Setyowati et al., 2017). Parents who work have limited time in sharing with children. This certainly will have an impact on the low stimulation given by parents to children (see. Cooklin et al., 2015). The implementation of stimulation and joint activities between parents and children requires time availability. The quantity and quality of parents' time with children must be a family priority. A study found that $65.6 \%$ of parents at home did not do activities with their children. $29.2 \%$ of parents prefer to be outdoors, $23.2 \%$ in stalls/shops and $5 \%$ in other places (Harmaini, 2013). Childcare requires commitment, knowledge, and skills. Without commitment, parenting will only last a little. Commitment here is not only meaningful but also offers time consciously to carry out parenting processes.

Given the complexity of the issue of childcare in the family, it is important for the country to make quality care as the main program through strengthening family functions (Parton, 1991), and improving the quality of education and parenting skills. Everywhere, the role of the family is very important in child development. The high involvement of families and their role in fulfilling children's rights will greatly depend on the acquisition of parental knowledge and education. Dronkers's (1994) study analyzing the influence of parent marital status on the attainment of child education in the Netherlands found that there is an effect of marital status on children's educational attainment, where children living in families with natural parents reach higher secondary education levels compared to those who live in single parent families. Using a cross-country data set, Pong et al. (2003) argued that single-parent families are more beneficial, compared to two parents' homes, in terms of family policies that equated resources. In a similar context, Jonsson and Gähler's (1997) study with the Swedish data set suggests that economic deprivation has a negative influence on children's achievement and besides, the possibility of a decrease in social capital and aspiration is likely to be in children who have lost parents with higher social position. Furthermore, Schlee et al. (2009) found the influence of social capital and resources on academic achievement in early childhood, with the highlighted results that parents' capital, rather than parents' social capital, is a better predictor of achievement. This shows that the characteristics of both parental social status and resources are very likely to influence the fulfillment of children's rights (see also, Kloosterman et al., 2010; Kaushal \& Nepomnyaschy, 2009; Pishghadam \& Zabihi, 2011; Havermans et al., 2014). In a study in China, Zhang et al. (2013) found that socioeconomic status (SES) affected several variations in children's abilities at an early age. Equally, Li et al. (2014) suggested the relationship of family socio-economic status and adolescent-family conflicts with adolescent obedience in the family. Some studies in the East involving social capital constructs also indicate the influence of family backgrounds and parent involvement on fulfilling children's rights (Wei, 2012; Leung, \& Shek, 2011; Guo et al., 2018). The increasing quantity and types of cases of violations of child rights in Indonesia today cannot be separated from the fragility and retention of parents in the implementation of child care (Nurick \& Johnson, 2001; Stark et al., 2012). Many forms of violation of children's rights occur because of the fragility of the family foundation. The protection of children should be carried out systematically from upstream to downstream with the main basis of strengthening family care. The main focus of this study is to see, describe and explore the quality of family education in fulfilling childcare rights. This can be seen from the education and skills of parents in the process of caring for children, direct involvement of parents in parenting and the quantity of parental time with children in care. So this study can understand the quality of family education and the increase in cases of child rights violations in Indonesia.

\section{Research Method}

This study uses a quantitative approach. The quantitative approach is used to measure the perceptions and practices of parents related to parenting while at the same time asking children about parenting by their parents. An opinion survey is a method applied to a quantitative approach. The survey was conducted nationally and covers 33 provinces in Indonesia. The survey represents family opinion (father, mother and child) in Indonesia. Children in this case are biological children who live in the families of selected respondents and are aged 10-18. The survey population is Indonesian families not individuals. So the unit of analysis of this survey is family. The sample framework in this study is a list of family heads who are at the lowest level of government, namely neighborhood groups. In order to be able to represent the opinions of all Indonesian families, respondents in this survey will be chosen randomly (probability sampling). The method used is multistage random sampling. Multistage random sampling is used to select the level of provincial, regency, village and neighborhood levels as survey locations. The next level is to choose the head of the family within the chosen neighborhood group and choose respondents in the family of the father, mother and especially the respondent of the child.

The sample selection process uses an instrument called a random number sheet. Instruments with random numbers generated through Microsoft excel programs that randomize the selection of samples can be accounted for and shown transparently. The number of samples or respondents in this survey were 800 families with a total of 2,400 respondents consisting of 800 father respondents, 800 respondents from mothers and 800 respondents from 
children spread across 33 provinces in Indonesia. The number of samples is methodologically permitted to make claims the margin of error of this survey is estimated to reach $5 \%$ at a $95 \%$ confidence level. This can be interpreted as follows: If the number of respondents who agree to a statement is as much as $70 \%$, then even if a similar survey is repeated 100 times, 95 times those who agree to the statement are always in the range of $66.5 \%$ to $73.5 \%$. The sample above is distributed proportionally according to the number of families in each province. This means that the samples in each province vary according to the size of the population in the province, as illustrated in table 1 .

Table 1. Survey Sample Distribution by Province

\begin{tabular}{|c|c|c|c|c|c|c|}
\hline No & Province & Population & $\begin{array}{l}\text { Number of } \\
\text { household }\end{array}$ & $\begin{array}{c}\text { Household proportion/ } \\
\text { national total household }\end{array}$ & $\begin{array}{l}\text { Proporsi } \\
\text { Sample }\end{array}$ & $\begin{array}{c}\text { Responden } \\
\text { (Family) }\end{array}$ \\
\hline 1 & Aceh & 4.612 .443 & 1.171 .562 & $2 \%$ & $2 \%$ & 10 \\
\hline 2 & Sumatera Utara & 13.502 .046 & 3.183 .619 & $5 \%$ & $5 \%$ & 40 \\
\hline 3 & Sumatera Barat & 4.793 .227 & 1.213 .112 & $2 \%$ & $2 \%$ & 10 \\
\hline 4 & Riau & 4.612 .763 & 1.152 .556 & $2 \%$ & $2 \%$ & 10 \\
\hline 5 & Jambi & 3.077 .641 & 821.270 & $1 \%$ & $1 \%$ & 10 \\
\hline 6 & Sumatera Selatan & 7.965 .720 & 2.042 .151 & $3 \%$ & $3 \%$ & 20 \\
\hline 7 & Bengkulu & 1.783 .788 & 479.382 & $1 \%$ & $1 \%$ & 10 \\
\hline 8 & Lampung & 8.127 .000 & 2.096 .516 & $3 \%$ & $3 \%$ & 20 \\
\hline 9 & Bangka Belitung & 1.235 .929 & 352.668 & $1 \%$ & $1 \%$ & 10 \\
\hline 10 & Kepulauan Riau & 1.489 .220 & 460.796 & $1 \%$ & $1 \%$ & 10 \\
\hline 11 & DKI Jakarta & 7.004 .186 & 1.800 .128 & $3 \%$ & $3 \%$ & 20 \\
\hline 12 & Jawa Barat & 43.084 .158 & 12.275 .491 & $19 \%$ & $19 \%$ & 150 \\
\hline 13 & Jawa Tengah & 34.567 .837 & 9.841 .123 & $15 \%$ & $15 \%$ & 120 \\
\hline 14 & DI Yogyakarta & 3.226 .752 & 964.982 & $1 \%$ & $1 \%$ & 10 \\
\hline 15 & Jawa Timur & 38.253 .021 & 11.350 .120 & $18 \%$ & $18 \%$ & 130 \\
\hline 16 & Banten & 10.208 .848 & 2.549 .705 & $4 \%$ & $4 \%$ & 30 \\
\hline 17 & Bali & 3.597 .603 & 949.645 & $1 \%$ & $1 \%$ & 10 \\
\hline 18 & Nusa Tenggara Barat & 4.912 .789 & 1.456 .944 & $2 \%$ & $2 \%$ & 20 \\
\hline 19 & Nusa Tenggara Timur & 4.767 .751 & 1.103 .964 & $2 \%$ & $2 \%$ & 10 \\
\hline 20 & Kalimantan Barat & 4.776 .243 & 1.198 .064 & $2 \%$ & $2 \%$ & 10 \\
\hline 21 & Kalimantan Tengah & 2.120 .761 & 588.734 & $1 \%$ & $1 \%$ & 10 \\
\hline 22 & Kalimantan Selatan & 3.668 .151 & 1.070 .720 & $2 \%$ & $2 \%$ & 10 \\
\hline 23 & Kalimantan Timur & 2.575 .072 & 677.747 & $1 \%$ & $1 \%$ & 10 \\
\hline 24 & Sulawesi Utara & 2.336 .178 & 641.725 & $1 \%$ & $1 \%$ & 10 \\
\hline 25 & Sulawesi Tengah & 2.827 .203 & 693.977 & $1 \%$ & $1 \%$ & 10 \\
\hline 26 & Sulawesi Selatan & 7.861 .947 & 2.008 .646 & $3 \%$ & $3 \%$ & 20 \\
\hline 27 & Sulawesi Tenggara & 2.306 .360 & 575.068 & $1 \%$ & $1 \%$ & 10 \\
\hline 28 & Gorontalo & 1.061 .672 & 289.029 & $0 \%$ & $0 \%$ & 10 \\
\hline 29 & Sulawesi Barat & 1.165 .627 & 283.894 & $0 \%$ & $0 \%$ & 10 \\
\hline 30 & Maluku & 1.580 .967 & 365.690 & $1 \%$ & $1 \%$ & 10 \\
\hline 31 & Maluku Utara & 1.110 .707 & 272.936 & $0 \%$ & $0 \%$ & 10 \\
\hline 32 & Papua & 2.838 .241 & 567.218 & $1 \%$ & $1 \%$ & 10 \\
\hline 33 & Papua Barat & 844.329 & 194.624 & $0 \%$ & $0 \%$ & 10 \\
\hline & Total & 237.896 .180 & 64.693 .806 & $100 \%$ & 100 & 800 \\
\hline
\end{tabular}


Survey data is collected by conducting face-to-face interviews with selected respondents. Interviews use questionnaires written in sequential sequence of questions. In other words, data collection is structured (structured interview). In this study, several questions were asked to the respondents, such as regarding the background of the demographic and about how long parents communicate with their children every day. Interviews were conducted by a number of interviewers. In order not to cause bias, they are trained first for one day. Training materials included understanding the aims and objectives of the research, the skills of selecting respondents and understanding each question in the questionnaire. There are two aspects of quantitative analysis used in treating survey data. First, trend analysis of certain indicators. This analysis is done by comparing proportions between one value and another value. Second, comparison analysis between variables. This analysis is done by crostabulating two variables. With this analysis method, information on differences between one variable and another variable will be obtained. The instruments used to process data are SPSS software.

\section{Results}

The opening of the Convention on the Rights of the Child (CRC) states that children for the development of their personalities must grow and develop with their families in a happy atmosphere. This principle was then adopted in Law No. 35 of 2014 concerning the second amendment to Law No. 23 of 2002 concerning child protection, which states that every child has the right to be cared for by his own parents, unless there are reasons and / or rules of law the legal one indicates that the separation is in the best interest of the child and is the final consideration.

\subsection{Sample Characteristics}

Family is the best care for children, but this can be realized if the quality of family education is good. Based on this study, it was found that formal education of parents is that most did not graduate from elementary school by $5.9 \%$ for fathers and $6.1 \%$ for mothers. A total of $41.9 \%$ of fathers graduated from elementary school and as many as $43.8 \%$ for mothers. This proportion decreases with increasing education levels. For junior high school level, as many as $20.5 \%$ of fathers are involved in study graduation and $23.8 \%$ for mothers. For high school levels, $26 \%$ of fathers and $22 \%$ of mothers passed the study. A small proportion of the sample also completed higher education, with parents, as many as $4.5 \%$ of fathers were undergraduate graduates and $3.3 \%$ for mothers, while postgraduate graduates only had a proportion of $0.3 \%$. Demographic characteristics carried out through this national survey need to be very concerned that the education of parents in the sample is mostly elementary school graduates, namely $41.1 \%$ for fathers and $43.8 \%$ for mothers. Low parent education will certainly have an impact on the low skills of parents in caring for children. This is in line with Wasinah's (2005) opinion which explains that people's education level directly and indirectly affects the quality of parent and child communication in care.

\subsection{Education and Knowledge of Parents Regarding Childcare}

Knowledge about childcare is a key word in improving the quality of parenting to children. Knowledge of good child development, practice and parenting skills, fulfilling physical and psychological needs will greatly help a positive contribution to quality care. Based on this study it was found that only $27.9 \%$ of fathers and $36.9 \%$ of mothers sought information about caring for children. This illustrates that the understanding of prospective parents when entering pre-marriage is very minimal in caring for and educating their children.

After marriage, it was found that only $38.9 \%$ of fathers and $55.9 \%$ of mothers sought information regarding childcare. The low parental participation in improving the quality of their knowledge related to child care and growth has the potential for wrongful care, and the parenting style applied by parents is not in accordance with the stages of child development. According to Fatimah, parents' mistakes in applying parenting to children can cause abnormal growth and development for children. Conversely, parents who are able to apply parenting well can produce normal child growth (Fatimah, 2012). Knowledge about parenting is more or less influenced by the formal education of parents. The formal education of parents in this study found that as much as $41.9 \%$ for fathers and $43.8 \%$ for mothers graduated from elementary school. Moreover, as much as $20.5 \%$ for fathers and $23.8 \%$ for mothers graduated from middle school, and $26 \%$ of fathers and $22 \%$ of mothers graduated from senior high school, while parents of college graduates were $5.9 \%$ for fathers and $4.5 \%$ for mothers. The level of education of parents and caregivers for their efforts in seeking information related to care can be seen in Figure 1. 


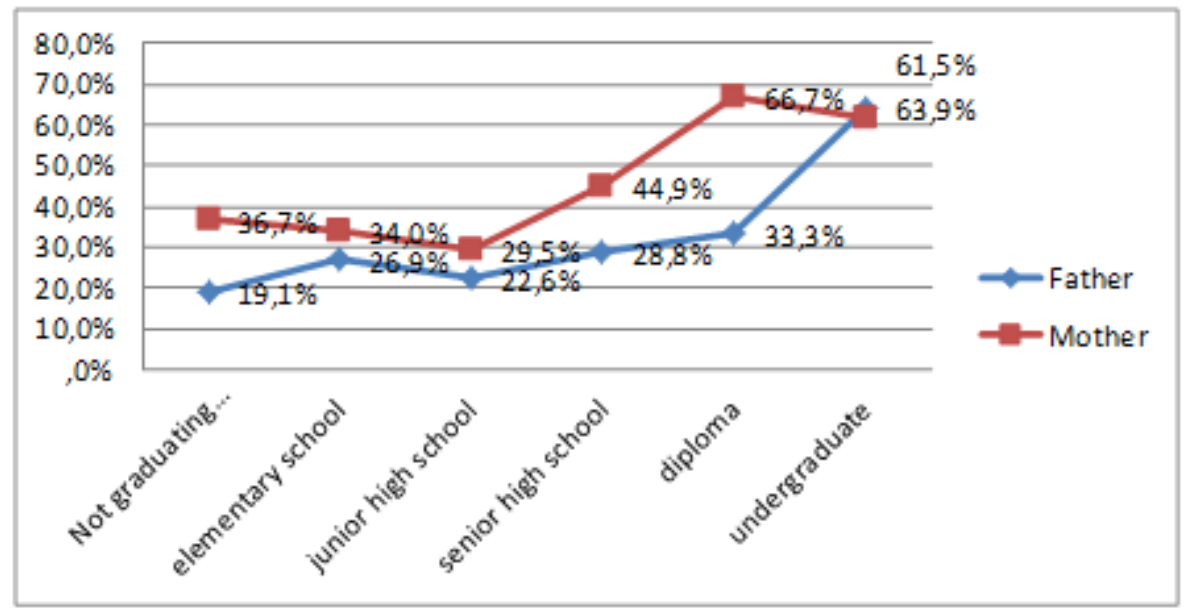

Figure 1. Cross-tabulation of father and mother education and efforts to seek knowledge about child care

The results of the crosstabulation between father and mother education on efforts to find information related to parenting showed that the better the education of parents, the better in finding information related to children. In this case, maternal education is very influential in efforts to find information about care (see. Pluess \& Belsky, 2010). The high percentage of parents with formal education is only elementary school graduates, being one of the factors causing limited knowledge and understanding of parents in providing quality care for children. There is a tendency for parenting patterns applied by parents at this time, and it is a duplication of the pattern of care received by previous parents so that there is no significant learning process and increased knowledge of parents in providing quality care for children.

\subsection{Involvement in Child Care}

Direct involvement of parents in parenting is very positive towards the process of child development, both physical, psychological, mental and social development (see. Kiernan \& Huerta, 2008). Parents' commitment not to divert the childcare process to others, such as grandmothers, grandparents, relatives, helpers, caregivers and others becomes very important. This study found that $26.2 \%$ of fathers and $25.8 \%$ of mothers stated that the childcare process was not helped and was not transferred to others.

This is in line with Widiasari and Pujiati (2017), stating that grandmother and grandfather are the parties who most often carry out the substitution role in the childcare process (see also. Smith \& Hancock, 2010). The low percentage of parents who do their own care without the help of others, can be interpreted that the process of parenting is more done by other people outside the parent.
Other parties that are predominantly involved in childcare are grandmothers, grandparents, families, relatives, housemaids and carers. Care for children outside of parents has the potential to cause children to experience developmental disorders, both physical, psychological, mental and social, as a result of the low quality of care received by children. In other words, the transfer of both permanent and temporary care has the potential to have an impact on the quality of childcare that can have an impact on the quality of child development.

Based on the results of crosstabulation between the number of children owned by parents and the transfer of care outside the nuclear family, this study found data that $55.4 \%$ of parents who have children more than 2 people have a greater chance of transferring childcare to others such as grandmothers, grandparents, families, relatives, housemaids and caregivers compared to families that have children less than 2 . Every family must prepare good parenting management in the event of transfer of care to reduce the impact of the transfer of care.

\subsection{Availability and Sufficiency of Communicating with Children}

Communication is the key to creating strong and close relationships between children and parents (see. Segrin et al., 2012; Dunn, 1993). The habit of parents in listening, telling stories, gathering and vacationing with children is a momentum to create quality care. This study found data that the quantity of parents' time to communicate with children is very small. In terms of quantity, the highest percentage of parents communicating with children is only 1 hour per day, which is $47.1 \%$ for fathers and $40.6 \%$ for mothers, as shown in Figure 2. 


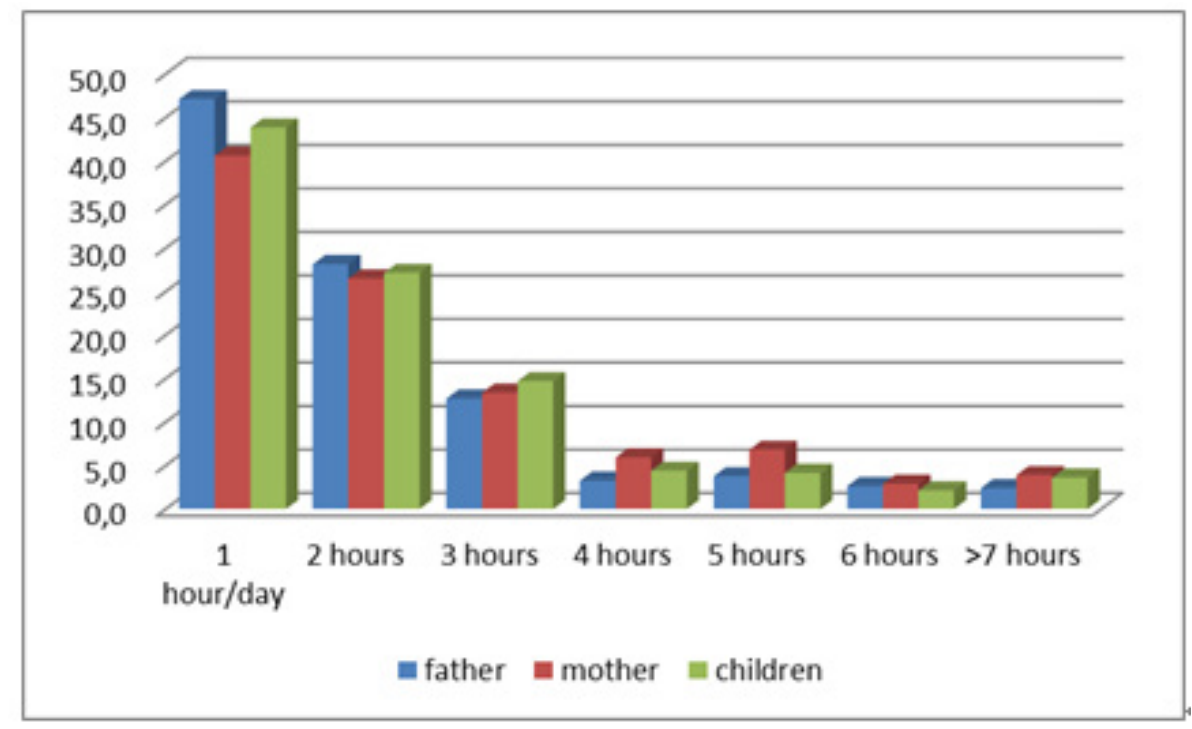

Figure 2. Quantity of Time of Parents Communicating with Children

The lack of time for parents to communicate with children has the potential for loss of familiarity, warmth and harmony in relations between parents and children in the family. This study found that parents with children more than 2 people had less time in communicating with children which was $51 \%$. The quantity of communication is the most tangible parenting practice to improve the quality of care for children. In addition, the quantity of communication still needs to be followed by the quality of the communication that concerns all aspects of child development and not only focuses on aspects of children's cognitive development.

\section{Conclusions}

Family quality in fulfilling child care rights is not good, one of which is influenced by the quality of parents' education. Education and knowledge of parents regarding childcare is still weak, where only $27.9 \%$ of fathers and $36.9 \%$ of mothers seek information on caring for and caring for children before marriage and only $38.9 \%$ of fathers and $56.2 \%$ of mothers seek information on the care of children after marriage.

Parental involvement directly in the process of parenting is also still low; only $26.2 \%$ of Fathers and $25.8 \%$ of Mothers stated that the process of parenting was not helped and was not transferred to others. This condition requires better management of care. The quantity and quality of communication time of parents with children is also still very minimal; in quantity the average time to communicate with children is only 1 hour per day in which $47.1 \%$ is for Father and $40.6 \%$ for mother. Meanwhile, parent communication is more dominant in academic affairs and is very less touching on the social life of children.

From these findings, this study underlines that families and parents have a strategic role in fulfilling childcare rights. Improving the quality of parental education is absolutely necessary. This can be done through parenting courses and training. Parents need to get debriefing related to parenting with new and sustainable models and parenting. With good and proper parenting, child development can take place normally and optimally. The government needs to issue policies and programs to improve family quality, significant support and continuation for families through coaching, training, guidance, socialization and development of parenting skills in parenting will reduce the occurrence of cases of violations of children's rights as a result of family and parent functions being released in childcare.

\section{REFERENCES}

[1] Coleman, J. S. (2018). Parents, their children, and schools. Routledge.

[2] Cooklin, A. R., Westrupp, E., Strazdins, L., Giallo, R. Martin, A., \& Nicholson, J. M. (2015). Mothers' workfamily conflict and enrichment: Associations with parenting quality and couple relationship. Child: care, health and development, 41(2), 266-277.

[3] Crittenden, P. M. (2013). Raising parents: Attachment, parenting and child safety. Routledge.

[4] Dronkers, J. (1994). The changing effects of lone parent families on the educational attainment of their children in a European welfare state. Sociology, 28(1), 171-191.

[5] Dunn, J. (1993). Young children's close relationships: Beyond attachment. Sage Publications, Inc.

[6] Epstein, J. L., Sanders, M. G., Sheldon, S. B., Simon, B. S., Salinas, K. C., Jansorn, N. R., ... \& Hutchins, D. J. (2018). School, family, and community partnerships: Your 
handbook for action. Corwin Press.

[7] Fatimah, L. (2012). Relationship between parenting and child development in RA Darussalam Sumber Mulyo Village, Jogoroto, Jombang (in Indonsian). Prosiding Seminas, 1(2).

[8] Firat, H. (2018). Grandparent-Grandchild Relationships in Turkish Children's Novels. Universal Journal of Educational Research, 6(10), 2047-2060.

[9] Government of Republic of Indonesia. (2014). Law Number 35 of 2014 concerning Amendments to Law Number 23 of 2002 concerning Child Protection. Jakarta: Government of Republic of Indonesia.

[10] Güder, S. Y., \& Ata, S. (2018). Father Involvement, Gender Perception and Children's Gender Stereotypes. Universal Journal of Educational Research, 6(8), 1637-1646.

[11] Guo, X., Lv, B., Zhou, H., Liu, C., Liu, J., Jiang, K., \& Luo, L. (2018). Gender differences in how family income and parental education relate to reading achievement in China: The mediating role of parental expectation and parental involvement. Frontiers in psychology, 9.

[12] Halmatov, M. (2018). Conflicts and Conflict Situation Settlement of Children of 5-6 Years Attending Pre-School Educational Institution. Universal Journal of Educational Research, 6(11), 2634-2640.

[13] Handayani, A., \& Munawar, M. (2015). Work-Family Balanced and Quality of Parenting in Optimizing Children Development. Indonesian Journal of Early Childhood Education Studies, 4(1), 11-18.

[14] Harmaini, H. (2013). Presence of Parents and Children (in Indonesian). Jurnal Psikologi, 9(2), 80-93.

[15] Havermans, N., Botterman, S., \& Matthijs, K. (2014). Family resources as mediators in the relation between divorce and children's school engagement. The Social Science Journal, 51(4), 564-579.

[16] Jonsson, J. O., \& Gähler, M. (1997). Family dissolution, family reconstitution, and children's educational careers: Recent evidence for Sweden. Demography, 34(2), 277-293.

[17] Kagan, R. (2014). Rebuilding attachments with traumatized children: Healing from losses, violence, abuse, and neglect. Routledge.

[18] Kaushal, N., \& Nepomnyaschy, L. (2009). Wealth, race/ethnicity, and children's educational outcomes. Children and Youth Services Review, 31(9), 963-971.

[19] Kiernan, K. E., \& Huerta, M. C. (2008). Economic deprivation, maternal depression, parenting and children's cognitive and emotional development in early childhood 1 . The British journal of sociology, 59(4), 783-806.

[20] Kloosterman, R., Notten, N., Tolsma, J., \& Kraaykamp, G. (2010). The effects of parental reading socialization and early school involvement on children's academic performance: A panel study of primary school pupils in the Netherlands. European Sociological Review, 27(3), 291-306

[21] Leung, J. T., \& Shek, D. T. (2011). Validation of the Chinese parental sacrifice for child's education scale. International journal on disability and human development,
10(3), 209-215.

[22] Li, X., Zou, H., Liu, Y., \& Zhou, Q. (2014). The relationships of family socioeconomic status, parentadolescent conflict, and filial piety to adolescents' family functioning in mainland China. Journal of Child and Family Studies, 23(1), 29-38.

[23] Minister of Social Affairs Republic of Indonesia. (2013). Minister of Social Affairs Regulation Number 21 of 2013 concerning Child Care. Jakarta: Minister of Social Affairs Republic of Indonesia.

[24] Mubarok, P. P. (2016). Positive Care Program to Improve the Mindful Parenting Skills of Youth Parents (in Indonesian). Psympathic: Jurnal Ilmiah Psikologi, 3(1), $35-50$.

[25] Nurick, R., \& Johnson, V. (2001). Putting child rights and participatory monitoring and evaluation with children into practice: some examples in Indonesia, Nepal, South Africa and the UK. PLA Notes, 42, 39-44.

[26] Parton, N. (1991). Governing the family: Child care, child protection and the state. Macmillan International Higher Education.

[27] Pishghadam, R., \& Zabihi, R. (2011). Parental education and social and cultural capital in academic achievement. International Journal of English Linguistics, 1(2), 50.

[28] Pluess, M., \& Belsky, J. (2010). Differential susceptibility to parenting and quality child care. Developmental psychology, 46(2), 379 .

[29] Pong, S. L., Dronkers, J., \& Hampden-Thompson, G (2003). Family policies and children's school achievement in single-versus two-parent families. Journal of marriage and family, 65(3), 681-699.

[30] Schlee, B. M., Mullis, A. K., \& Shriner, M. (2009). Parents social and resource capital: Predictors of academic achievement during early childhood. Children and Youth Services Review, 31(2), 227-234.

[31] Segrin, C., Woszidlo, A., Givertz, M., Bauer, A., \& Taylor Murphy, M. (2012). The association between overparenting, parent-child communication, and entitlement and adaptive traits in adult children. Family Relations, 61(2), 237-252.

[32] Setyowati, Y. D., Krisnatuti, D., \& Hastuti, D. (2017). Effect of parental readiness and psychosocial parenting on children's social development (in Indonesian). Jurnal Ilmu Keluarga \& Konsumen, 10(2), 95-106.

[33] Smith, G. C., \& Hancock, G. R. (2010). Custodial Grandmother-Grandfather Dyads: Pathways Among Marital Distress, Grandparent Dysphoria, Parenting Practice, and Grandchild Adjustment. Family Relations, 59(1), 45-59.

[34] Stark, L., Bancroft, C., Cholid, S., Sustikarini, A., \& Meliala, A. (2012). A qualitative study of community-based child protection mechanisms in Aceh, Indonesia. Vulnerable children and youth studies, 7(3), 228-236.

[35] Wasinah. (2015). The role of parents 'authoritative parenting, parents' education and the number of siblings on children's independence (in Indonesian). Jurnal ilmiah keluarga dan konseling 10(2). 
[36] Wei, D. (2012). Parental influence on Chinese students' achievement: a social capital perspective. Asia Pacific Journal of Education, 32(2), 153-166.

[37] Widiasari, Y., \& Pujiati, D. (2017). Early Childhood Care for Worker Parents (in Indonesian). Jurnal Indria (Jurnal Ilmiah Pendidikan Prasekolah dan Sekolah Awal), 2(2).

[38] Zhang, Y., Tardif, T., Shu, H., Li, H., Liu, H., McBride-Chang, C., ... \& Zhang, Z. (2013). Phonological skills and vocabulary knowledge mediate socioeconomic status effects in predicting reading outcomes for Chinese children. Developmental psychology, 49(4), 665. 